\title{
Promýšlení Weberova konceptu odkouzlení: Výzkum opětovného okouzlení jachtingem v post-komunistické České republice ${ }^{1}$
}

\author{
Revisiting Weber's Concept of Disenchantment: An Examination \\ of the Re-enchantment with Sailing in the Post-Communist \\ Czech Republic
}

Dino Numerato

\begin{abstract}
The significance of sport as a social practice remains hidden at the margins of sociology. This article aims to highlight the social significance of sport by providing a sociological interpretation of the transformations of sailing in Czechoslovakia, and later in the Czech Republic, following the Velvet Revolution of 1989. These sport-related changes are understood to be consequences of wider sociocultural, economic and political transformations. Drawing on ethnographic fieldwork of the Czech sailing movement, I argue that during Czechoslovakia's communist period, a time when sailing was labelled pejoratively as a 'bourgeois sport', it actually experienced a 'golden age' of enchantment. Based on Weber's concept of disenchantment and its subsequent developments in contemporary sociology, this article demonstrates how this earlier enchantment was jeopardized by disenchantment threats that occurred after 1989, and how sailing has once again been re-enchanted in the current period.
\end{abstract}

KEY WORDS Czech Republic, disenchantment, enchantment, political transformation, re-enchantment, sailing, sporting culture

\section{Úvod: „Před osmnácti lety“}

$\mathrm{V}$ rámci etnografického výzkumu, který byl primárně zaměřen na organizaci českého jachtingu, jsem měl př́ležitost potkat řadu aktérů zapojených do jachtingového hnutí. Naslouchaje jejich př́běhům, které se týkaly jak praktikování sportu, tak jeho organizace, jsem se pozastavil nad jednou skutečností: časností, s níž jachtaři uvozovali svá vyprávění výrokem „před osmnácti lety“, odkazujíce se ke komunistickému režimu a jeho pádu v listopadu 1989.

Sociální studia. Katedra sociologie FSS MU, 1/2011. S. 37-52. ISSN 1214-813X.

1 Tento článek byl původně publikován pod názvem „Revisiting Weber's Concept of Disenchantment: An Examination of the Re-enchantment with Sailing in the Post-Communist Czech Republic" v časopise Sociology, 43 (3): 439-456. Online verze článku, který je zde přeložen se svolením vydavatelství Sage, je dostupná na www: <http://soc.sagepub.com/cgi/content/abstract/43/3/439> 
Časté opakování této poznámky naznačilo, jak úzce sport byl a je propojen s širšími procesy socio-kulturní, ekonomické a politické transformace. Sociologické metanarace, jež popisují období transformace ve stř̌ední a východní Evropě, takové každodenní chápání role sportu často opomíjí. A i když dané transformační období přitáhlo řadu antropologických výzkumů k zájmu o Českou republiku a okolní země (Hann 2007), žádná z etnografických studií nebyla zaměřena na sport.

Cílem následujících sociologických interpretací současného vývoje v českém jachtingu je překlenutí takové mezery. Prostředí českého jachtingu a jeho transformace je zkoumáno optikou Weberova konceptu odkouzlení (Weber 1971) a jeho rozvinutí v současné sociologii, s důrazem na komplementární koncepty okouzlení a opětovné okouzlení.

Záměrem této stati, založené na etnografické studii, je zdůraznění role sportu coby významné sociální praktiky, a současně i porozumění oblasti, jež doposud zůstávala na okraji sociologické pozornosti (Dunning 2004). Empirická evidence navíc slouží k obohacení sociální teorie tím, že testuje a rozvíjí některá konceptuální tvrzení. Kromě epistemologického záměru, a to obohacení konceptu odkouzlení o novou empirickou evidenci, směřuje stat' i k cílům analytickým, a to konkrétně $\mathrm{k}$ pochopení povahy politické transformace a dalších s ní spjatých procesů.

Jachting byl vybrán z několika důvodů. Jako sportovní disciplína, jež byla oficiální komunistickou ideologií označována za buržoazní (podobně jako např́íklad golf nebo tenis), se jachting také značně proměnil $\mathrm{v}$ kontextu širších makro-sociálních podmínek. Zatímco v období komunismu si jachtaři primárně hájili svůj vlastní sport, po sametové revoluci v roce 1989 museli reagovat na nově se vynořující hrozby v podobě poklesu dobrovolnictví, profesionalizace a komercionalizace sportu, dopadu nových technologií nebo pronikání jachtingu do masových médií. Tento živelný proces proměny sportovní kultury v reakci na neustávající proměny vnějšího světa představuje svým způsobem jedinečný objekt sociologické analýzy. Relativně malá členská základna českého jachtingového hnutí navíc umožnila uchopit zkoumaný fenomén $\mathrm{v}$ jeho komplexnosti, udržet nutně holistickou perspektivu a pochopit každodenní povahu sociálních vztahů produkovaných a reprodukovaných jachtaři.

Jachting v České republice rozhodně nepatří k nejrozšiřrenějším sportům. ${ }^{2}$ Kvůli nedostupnosti moře je praktikován hlavně na přehradách a rybnících, nebo dokonce na nádržích či řekách, a pro spíše malou skupinu provozovatelů tohoto sportu si uchoval zvláštní, okouzlující význam. Podstata okouzlující povahy jachtingu je reprezentována všudypř́tomnými, na hraně romantické idealizace balancujícími obrazy s jachtami, jež zdobí nejen jachtařské kluby, ale i kanceláře a domovy jachtařù. Okouzlující povaha jachtingu je zjevná i z vousů upravených v kapitánském stylu, značkových větrovek nebo vodotěsných digitálních hodinek, které je možné spatřit na rukou jachtařủ nejen na vodě, ale i v běžném, každodenním životě.

Dané aspekty okouzlení jsou spjaty spíše s každodenním významem slova, který okouzlení spojuje se zevnějškem. Jak bylo naznačeno výše, cílem tohoto článku bude překročení

2 Podle žebříčku ČSTV založeném na počtu registrovaných členů je jachting na 26. místě mezi 80 sportovními disciplínami v České republice. V roce 2006 měl ČSJ 4559 členů organizovaných do 144 klubů (ČSJ 2006). 
vnější scenérie. Stat' bere v úvahu samotnou podstatu sociálního života v jachtingovém hnutí a používá termínu okouzlení $v$ jeho sociologickém významu.

Tento článek tak rozvijí myšlenku, že v průběhu komunistického období si jachtaři vybudovali k jachtingu specificky okouzlující vztah. Při analýze procesu transformace jachtingu coby sociální praxe $\mathrm{v}$ Československu a později v České republice se tato studie zaměřuje na následující otázky: Za prvé, jaké mechanismy přispěly $\mathrm{k}$ okouzlení jachtingu $\mathrm{v}$ období komunistického režimu? Za druhé, jaké odkouzlující hrozby přispěly k oslabení vazeb mezi jachtaři a jejich sportem? Za třetí, jaké mechanismy přispěly $\mathrm{k}$ opětovanému okouzlení jachtingem?

Tento článek nejdř́ve pojednává o konceptu odkouzlení. Poté se zabývá akademickou reflexí jachtingu a moderního sportu. Následující části jsou pak založeny na vyprávěních sociálních aktérů, týkají se transformace jachtingu a jsou ukotveny v rozvíjeném teoretickém rámci. Závěrečná diskuse pak promýšlí implikace těchto vyprávění pro sociologii sportu a pro sociologii obecně.

\section{Okouzlení, odkouzlení a opětovné okouzlení}

Termín odkouzlení poprvé uvedl do sociologie Max Weber při výzkumu vývoje moderní společnosti. ${ }^{3}$ Zabývaje se intelektualizací a racionalizací a jejich destruktivním dopadem na humanitu, použil termínu odkouzlení poprvé v roce 1919 v přednášce „Věda jako povolání určené publiku mnichovských studentů (Weber 1971: 139). Termín balancující mezi metaforou a konceptem se stal pevnou výbavou sociologického jazyka.

Weber ve své analýze reflektoval zejména makro-sociální povahu modernity. Jeho spíše pesimistická vize se soustředila na hegemonii instrumentální racionality, mizející sdílený kognitivní význam a slábnoucí sílu tradičních sociálních institucí a metafyzických předpokladů a na všudypř́ítomné zvládání sociálního života kalkulací (Weber 1971, 1998). Obecně odkouzlením odkazoval k mizející morální, kognitivní a interpretační jednotě, připisované tradičním společnostem (Gane 2002).

V pozdějších sociologických pojednáních nebyly odkouzlující tendence vnímány pouze jako nezvratitelné a izolované. Chápání termínu odkouzlení se odklonilo od původního významu. Teoretické rozvíjení pojmu bylo spjato s důrazem na procesy okouzlení a opětovného okouzlení (Jenkins 2000). Někteří myslitelé poukázali na skutečnost, že pozdně moderní aktér může najít v moderních institucích jisté kouzlo tím, že si je přivlastní a že pro něj nabudou přirozenosti (Cassegard 2001). Někteří autoři dokonce tvrdili, že rozum, a tedy racionalita, vybavuje sociálního aktéra smyslem pro okouzlující svobodu (Bennett 2001). Na straně druhé, v kritice okouzlení jsou sociální aktéři vnímáni coby méně emancipovaní, a to zejména ve chvílích, kdy se z okouzlení stává záměrný produkt racionálních a strategických cílů.

3 Myšlenka odkouzlující povahy moderního sportu nebyla teoretizována výlučně s odkazem na Webera. Podle Giulianottiho (2004: 236) např́klad adaptace Baudrillardových tezí v sociologii sportu může pomoci k zachycení „odkouzlující instrumentality moderního sportu“. Zaměření na odcizující kvality moderního sportu je bytostně spjaté s přístupem založeným na marxistické teoretické tradici (viz Porro 2002). 
V této perspektivě sociální vědci rozvíjeli úvahy o okouzlujícím potenciálu ryze moderní instituce, jakou je věda (Beck 2004 [1992]), zmínili se o kouzlu technologie (Jenkins 2000), moderní spotřeby a zábavy (Korczynski a Ott 2006, Langer 2002, Ritzer 1999, Ritzer a Stillman 2001), masových médií (Numerato 2005a, 2005b; Silverstone 1999), nebo dokonce byrokracie (Casey 2004).

Nejenže se zvýšená pozornost věnovaná okouzlení a opětovnému okouzlení v pozdní modernitě stala inherentní součástí akademického rozvíjení Weberova konceptu, ale rozum coby explanans procesu odkouzlení nahradily emoce, pocity, osobní zkušenost, nebo dokonce intuice, sny a fantazie (Campbell 1992, Ritzer 1999). Větší důraz byl kladen na mikro-sociální úroveň každodenní zkušenosti ve vztahu k makrosociální úrovni (Gellner 1987, Numerato 2005b, Sojak 2006). Pojednání z oblasti antropologie a kulturální sociologie navíc při vysvětlení podstaty okouzlení zdůraznila důležitost symbolické konstrukce významu (Alexander 2004, Gell 1988, Schneider 1993).

Tyto výše uvedené myšlenky mají několik implikací pro následující interpretaci současného a historického vývoje jachtingu v České republice. Za prvé, vztah mezi jachtaři a jejich sportem je interpretován skrze teoretický rámec, v němž jsou odkouzlující procesy pevně spjaty s procesy okouzlení a opětovného okouzlení. Okouzlení je vnímáno jako každodenní reprodukce sociálního systému kolektivně sdílených významů, jež váží sociální aktéry k sociálním institucím. Odkouzlení, na straně druhé, představuje proces, při němž vazby mezi sociální institucí a sociálními aktéry slábnou. Opětovné okouzlení je pak chápáno v termínech následných nebo paralelních reakcí na hrozby odkouzlení, při nichž se sociální aktér přizpůsobuje nově se vynořujícím makro-sociálním podmínkám a částečně tak obnovuje principy bývalého okouzlení. Za druhé, detailnímu postihnutí mikro-sociálních principů okouzlení napomáhá důraz kladený na osobní každodenní zkušenost a pocity. Za třetí, dynamiky mezi makro a mikro-sociální úrovní napomáhá zkoumat situování zkušenosti v kontextu politické, ekonomické a socio-kulturní transformace. Za čtvrté, zohledněna je i symbolická dimenze, která zahrnuje povahu komunikace v českém jachtařském hnutí.

\section{Jachting a povaha pozdně-moderního sportu optikou sociologie}

Akademická reflexe jachtingu je poměrně vzácná. V nejrozšǐřenějších studiích byl jachting téměř pokaždé představen $\mathrm{v}$ souladu se svým veřejným obrazem, tedy jako sport, který praktikují dominantní sociální tř́́dy (Bourdieu 1978, 1984). Tato myšlenka exkluzivity byla dále rozvíjena ve studiích, jež se pokoušely ověřit Bourdieuho přístup. Někteří autoři potvrdili vazbu jachtingu na vyšší tř́dní pozice (Scheerder a kol. 2002) a skutečnost, že jachting funguje jako symbolický znak distinkce v systému spotřeby (Falt 1981). Jiné studie, jež odkazovaly na exkluzivitu jachtingu, analyzovaly sportovní praxi jako maskulinní prostor, v němž dochází k reprodukci genderových nerovností (Bricknell 1999, Crawley 1998).

Výzkum jachtingu však nebyl výlučně zaměřen na jeho exkluzivitu. Aversa (1986) se zabýval tím, jak ve Spojených státech mizela homogenní a distinktivní povaha jachtingu. Macbeth (1986) ve své studii specifické subkultury oceánských jachtařů poukázal na „deviantni' potenciál, založený na environmentální zodpovědnosti jachtařu. Soustředil se na mezinárodní alternativní komunity, které drží pospolu jako produkt sdílených sociálních významů 
a vzorců jednání a vyznačují se nízkou spotřebou, blízkým vztahem k př́rodě a vysokou mírou sebedůvěry. Bass (1990) se zaměřil na pocity a emoce a na tělesnou zkušenost spjaté s jachtingem.

Pro následující analýzu jachtařské kultury v České republice je relevantní zejména druhý zmíněný proud studií, protože nespojuje jachting $\mathrm{s}$ trrídním statusem, a zároveň nabízí svědectví o okouzlujícím potenciálu pozdně moderního sportu. Tento druhý bod, který se týká kvality sportu, byl naznačen také $\mathrm{v}$ jiných akademických studiích, i když za použití odlišného slovníku. V textech založených na figurativní sociologii jsou moderní sport a volný čas pojímány jako zdroje př́ijemného vzrušení (Elias a Dunning 1986), fungují jako prostředky kolektivní identifikace a představují hlavní zdroj významu v každodenním životě (Dunning 1986). Podobně byl okouzlující potenciál sportu postižen ve Frankenbergově (1957) hustém popisu sociálního života komunity v severním Walesu, v níž hrál ústřední roli fotbal. Z perspektivy funkcionalismu byl fotbal dokonce chápán coby náhrada za náboženství (Coles 1975).

Okouzlující potenciál moderního sportu byl v řadě kritických studií moderního sportu inspirovaných Weberem spíše opomíjen. Zaměřením na racionalizaci, instrumentalitu, kalkulaci, standardizaci nebo byrokratizaci tyto studie vyzdvihovaly především odcizující charakter moderního sportu (viz např́ílad Cantelon a Ingham 2002, Guttmann 1978, Ingham 2004). I tato studie rozvíjí Weberovy myšlenky, nicméně zdůrazňuje, že současný sport může nést pro své provozovatele okouzlující význam, byt' jejich vztah ke sportu může být současně vystaven hrozbě odkouzlení. K pochopení těchto dynamik mezi odkouzlením a okouzlením je třeba zohlednit jak sociální význam, který sociální aktéri sportu připisují, tak makro-sociální kontext, v němž k tvorbě sociálního významu dochází.

\section{Poznámky k metodologii}

Data prezentovaná $\mathrm{v}$ tomto článku jsou součástí širší etnografické studie zaměřené na organizaci sportu a sociální dopad sportovního managementu a sportovní praxe. Empirická evidence byla nashromážděna zejména prostřednictvím polo-strukturovaných rozhovorů, v kombinaci s nezúčastněným pozorováním a sběrem dokumentů. Terénní výzkum proběhl od ledna do listopadu roku 2007 a byl doprovázen průběžnou analýzou sekundárních dokumentů, která začala v polovině roku 2006 a trvala do prvních měsíců roku 2009.

Je třeba poznamenat, že jsem do pole jachtingu vstoupil jako úplný outsider, bez předchozí zkušenosti s jachtařskou praxí a obeznámenosti s jachtingovou komunitou. Pozice cizince (srovnej Simmel 1950) v této komunitě mě vybavila jistou citlivostí k sociologicky relevantním fenoménům a umožnila mi klást otázky a problematizovat aspekty jachtařské reality, jež by jinak mohly být brány za dané. Př́stup do terénu byl neproblematický, a to díky obecné dostupnosti kontaktů na respondenty a díky otevřenosti jachtařů, kteří často popisovali svoji komunitu a své kolegy jako prátelské a vstrrícné, a také jako transparentní a otevřené. Tyto sebe-definice byly potvrzeny v průběhu terénního výzkumu, při němž byli jachtaři ochotní sdílet vlastní zkušenosti (terénní poznámky, např́iklad vyhlášení ankety Jachtar̆ roku, Praha, 6. února 2007; regata na národní úrovni, Nové Mlýny, 29. záŕí 2007).

Významný objem dat byl nashromážděn prostřednictvím čtyřiceti polo-strukturovaných rozhovorů, které jsem uskutečnil s funkcionáři Českého svazu jachtingu (ČSJ) na národní 
a krajské, respektive oblastní úrovni a s představiteli jachtařských oddílů. Každý z respondentů byl bývalým nebo současným aktivním jachtařem, působícím na amatérské či vrcholové a elitní úrovni. Evidence nashromážděná prostřednictvím polo-strukturovaných rozhovorů, zpravidla nahrávaná na diktafon, byla dále posílena řadou neformálních konverzací s jachtaři nebo rodiči mladých jachtařu při různých př́ležitostech. Nezúčastněná pozorování z průběhu sportovních klání nebo zasedání výkonného výboru ${ }^{4}$ nabídlo méně obtrusivní prístup. Analýza dostupných dokumentů, jako napríklad webových stránek ČSJ, jachetních klubů nebo asociací jachetních tříd, zápisů ze zasedání, programových dokumentů nebo novinových článků (kompletní monitoring př́spěvků o jachtingu $\mathrm{v}$ tištěných médiích $\mathrm{v}$ roce 2006), ročenek ČSJ nebo dvou knih publikovaných národním svazem u př́ležitosti výročí 100 a 110 let jachtingu v Čechách (ČSJ 1993, 2003), prrispěla k dokreslení obrazu o jachtingovém hnutí.

\section{Okouzlení: Jachtařská rodina}

Někteří z oficiálních politických představitelů komunistického režimu označovali jachting pejorativně jako buržoazní sport. To však podle mnoha jachtařů nijak neomezilo rozvoj jachtingu, který naopak v období komunistického Československa prožíval svá zlatá léta (terénní poznámky a neformální komunikace při různých př́ležitostech, například školicí semináŕ pro rozhodčí, Vlašim, 10. března 2007; regionální regata, Máchovo jezero, 13. května 2007). Př́iznačný komentář $\mathrm{k}$ povaze jachtingu je možné nalézt $\mathrm{v}$ knize publikované u př́iležitosti stého výročí jachtingu v České republice:

Těžká a pro mnohé tragická poúnorová doba přinesla paradoxně i podmínky pro rozvoj jachtingu. Lidé nemohli cestovat do zahraničí, nemohli podnikat a tak hledali únik z reality všedního dne do prátelského prostředi a kamarádství, které v jachtklubech nalezli. (ČSJ 1993: 12)

Tato vzpomínka $\mathrm{z}$ historie jachtingového hnutí předznamenává pět dimenzí, $\mathrm{v}$ rámci nichž mohou být procesy odkouzlení interpretovány a analyzovány. Zatímco zmínka o tragické po-únorové době ukazuje na důležitost politické dimenze, nemožnost zakládat soukromé podniky naznačuje relevanci dimenze ekonomické. Komentář o přátelském prostředí a kamarádství pak implikuje důležitost sociální a symbolické dimenze. Pátá, sportovní dimenze je pak inherentně prítomná $\mathrm{v}$ tématu.

V podmínkách, $\mathrm{v}$ nichž byl jachting označen za buržoazní sport, představovala oficiální politická ideologie nepřítele sportovního hnutí. Jachtaři se ve vztahu k bývalému oficiálnímu politickému režimu, který je izoloval od západního světa, vymezovali často negativně. Izolace pro většinu $\mathrm{z}$ nich znamenala nemožnost cestovat do zahraničí, a zejména $\mathrm{k}$ moři, a znemožnila jim tak potkávat se se zahraničními jachtaři. Kvalitní vybavení bylo téměř nedostupné. Organizace jachtingu byla navíc podř́zena pravidlům centrálního plánování a organizaci

4 Zúčastnil jsem se několika výročních konferencí, zasedání výkonných výborů a expertních komisí, čtyř regat uspořádaných jak na krajské, respektive oblastní, tak na národní úrovni. Několikrát jsem se coby pozorovatel zúčastnil tréninků v jachetních oddílech. Zúčastnil jsem se také vyhlášení ankety Jachtař roku a dvou letních jachtingových táborů pro děti a mládež. 
sportu v bývalém Československu (Kostka 1978). Možnost ř́dit sport autonomně, skrze principy demokratické a občanské angažovanosti, byla omezena.

I tak měly tehdejší podmínky pro sport nějaké pozitivní důsledky. Členství ve sportovních klubech, účast na závodech a tréninky mládeže nabízely mnoha jachtařům legitimní omluvu pracovní absence nebo neúčasti na povinných politických setkáních. Dobrovolnictví ve sportu totiž představovalo činnost, jež byla komunistickou ideologií nahlížena pozitivně. Jinými slovy, to, co bylo oficiálně interpretováno jako budování socialistické společnosti, mělo v jistém smyslu opačný význam pro ty, kdož se podíleli na dobrovolnictví. Pro mnoho jachtařů bylo dobrovolnictví ve prospěch hnutí př́ležitostí, jak uniknout z politické reality (ČSJ 1993; $<\mathrm{http}:\|w w w . c y k . c z>,<\mathrm{http}:\| w w w . j a c h t i n g . c z>)$. Přesněji, jachting znamenal částečný únik z této reality tím, že čelil její invazivnosti. V jistém smyslu ale i jachting zůstal navázán na sféru politiky, protože otevřel prostor pro individuální rezistenci na úrovni každodenního života.

Politické okouzlení bylo dále posíleno ekonomickými podmínkami. Továrny vlastněné státem a centralizovaná, státem řízená politika sportu garantovaly jachtingovým klubům určitou míru jistoty a př́mou finanční podporu. Tyto pravidelné zdroje však nebyly zdaleka dostačující $\mathrm{k}$ tomu, aby přispěly $\mathrm{k}$ dosažení mezinárodního standardu. Celkový finanční př́íspěvek byl velmi skromný, což přimělo jachtaře $\mathrm{k}$ hledání jiných způsobů, jak se vyrovnat s omezeným vybavením a zařízením.

V reakci na nedostatečnou veřejnou podporu se objevilo mnoho individuálních strategií, jež pomohly překlenout oficiálně deklarovaný a praktikovaný rovnostářský př́stup $\mathrm{k}$ veřejné podpoře sportu. Jak je často v jachtařském hnutí opakováno, , co garáă, to jachtingový klub “. Jachtaři z různých koutů republiky prípomínají historky o tisících hodinách strávených po nocích a o víkendech stavbou plachetnic a lodí a ličí strastiplné cesty, jimiž se dostávali $\mathrm{k}$ nedostatkovému vybavení a materiálu. Okouzlující povaha těchto nadšeneckých podomních aktivit je dobře zobrazena $v$ následujícím tvrzení jednoho ze starších ${ }^{5}$ jachtařù:

My jsme v klubu mèli 18 Fireballi̊. A Fireball v tej době znamenalo, že jsme koupili za pět tisíc stavebnici z Neratovic a postavili jsme lod'. A to bylo výhodný, nebo, dobrý to bylo pro ty lidi, že si toho vážili. Že se vo to starali, něco se naučili, mezi sebou jsme si pomáhali... ${ }^{6}$

Kromě stavění lodí strávili členové jachetních oddílů tisíce hodin povinným dobrovolnictvím a výstavbou zázemí jachetních klubů. Mnozí jachtaři připomínají Akci Z, původně ryze dobrovolnou činnost, jež se stala povinnou součástí centrálního národního plánovaní. Jachtaři si byli nuceni pořizovat vybavení $\mathrm{v}$ zahraničí, a to především v západních zemích, $\mathrm{s}$ čímž se otevřela další témata. Jachtaři si vyměňovali nápady týkající se toho, jak neplatit clo, jak se dostat k západní měně nebo jak překonat problém s nízkou hodnotou československé koruny.

Na strasti komunistického omezení reagovali pašováním benzínu a jeřábování nebo kotvení a $\mathrm{v}$ západních př́istavech a marínách platili $v$ naturáliích; místo západní měny platili českým pivem nebo náhradními díly na škodovku. Ti, kteří mohli oficiálně cestovat do západních

5 Jachtaři jsou podle věku rozděleni na mladou (méně než 40 let), střední (40-64 let) a starší generaci (65 let a více).

6 Znění citací nebylo s ohledem na posílení autenticity nijak upravováno. Některé z citací jsou ve srovnání s anglickou verzí článku pozměněné a rozšířené. 
zemí, at' už jako elitní jachtaři nebo díky pracovním povinnostem, mnohdy během svých cest obětovali vlastní pohodlí a použili tak peníze ušetřené za diety na nákup vysoce kvalitního vybavení (terénní poznámky, napríklad ČYK Praha, 18. dubna 2007; ČSJ 1993; rozhovory s jachtaři střední a starší generace). Tento př́stup je dobře dokumentován tvrzením jednoho bývalého jachtaře:

Za bolševika byl problém prostě sehnat materiál. Já vím, že pro ty naše chlapce, když jezdili na Optimistu, tak jsme přivezli plachtu ze Španělska. My jsme s manželkou oba dva muzikanti, a když jsme byli tadys Moravskou filharmonií ve Španělsku, tak jsme si schovávali diety do kapsy a za ušetřené penize jsme jim tam koupili Španělskou plachtu tehdy nejnovější. (muž, starši generace)

Náročné materiální a ekonomické podmínky a častá vysoká účast na závodech přispěly k posílení sociálních vazeb v rámci jachtingového hnutí. Princip „udělej si sám“ spolu s kolektivně sdíleným know-how posílily mezi jachtaři komunitního ducha. Označení „komunita“ zde není akademickou abstrakcí; termín často použivali samotní jachtaři a v některých okamžicích dokonce přistupovali k intimnějšímu označení ,jachtařská rodina“ (terénní poznámky, např́iklad oblastní regata, Srby, 19. květen 2007; zasedání výkonného výboru ČSJ, Praha, 19. dubna 2007). Těsnost osobních vazeb přispěla i k posílení mezilidské důvěry. To je patrné z příběhu jednoho z jachtar̆u:

A já jsem to prožival jako malej kluk, že já jsem měl zhruba sedm tisic strejdů a tet po republice. A ty děti, který byly třeba na břehu, tak ty byly jaksi celý tý společnosti, toho kolektivu, který byl třeba na tom mistrovství republiky. Mưj bratr, kterej je o šest mladši, tak [...] jako ročni ditě už byl s maminkou na závodech, na mistrovstvi republiky a byl v kočárku a tam ten, kdo ho měl hlídat, tak šel na rozjižd'ku, tak napsal na stan: „Juraj je u Bratislaváků, dal jsem mu vajička míchaný, nemá hlad a je v suchu. “ Přišlo se do Bratislavy-venkov a tam bylo: „Dostal slaninku a je na jižni Moravě. “ A tak to prostě maminka hledala, jak to ditě kolovalo a skutečně pečovali jako ty lidi vzorně. (muž, starši generace)

Důležitost sociálního prostredí byla zdůrazněna prostředím, $\mathrm{v}$ němž okouzlení probíhalo. Omezení dané nízkým počtem vhodných vodních ploch bylo zesíleno i mírnými klimatickými podmínkami, díky kterým se některé víkendové regaty proměnily v čekání na vítr. Mnoho regat se tak stalo spíše společenskými setkáními než sportovními událostmi. Jachtaři si s jistou nostalgií vybavují dlouhé víkendy, které začínaly nekonečnou a někdy strastiplnou cestou, spaní ve stanech, hraní divadla, hru na kytaru a zpívání u táboráku a popíjení piva ze sudu. Tato sportovně-společenská setkání nebyla přerušena ani v zimě, kdy byly jachtařské regaty nahrazeny ski regatami, jinými slovy, kdy lodě byly nahrazeny lyžemi (terénní poznámky z neformálního rozhovoru $\mathrm{v}$ jachtařském klubu, 14. března 2007).

Okouzlení budované skrze sociální pouta bylo posíleno i symbolicky: skrze sdílené porozumění a komunikaci. Komunikace mezi jachtaři byla často založena na interakci tváří v tváŕ. Jachtaři se vzájemně oslovovali př̌zdívkami a tykali si (jak to ostatně platí dodnes). Množství historek sdílených v kolektivní paměti, jež se týkají různých večírků, regat, logistiky a přepravy lodí, vytvořily bázi pro vzpomínání a diskuse, a tím i pro budování komunitních hodnot a významů. 
Analytický výklad ve čtyřech předcházejících dimenzích - politické, ekonomické, symbolické a sociální - se již implicitně dotknul páté, sportovní dimenze okouzlení. Navzdory vůli po vítězství, která je vlastní modernímu sportu jako takovému, byla s komunistickým režimem spjatá specifická povaha sportu. Za prvé, nedostupnost zdrojů přispěla $\mathrm{k}$ vytvoření téměř totožných startovních pozic; u kterých byla omezena role vybavení, kvality lodí apod. Za druhé, jachting nebyl vnímán výlučně skrze svou soutěživou povahu. Důraz byl kladen i na sociální dimenzi sportovních klání. Za třetí, podle mnoha jachtařŭ sport nutně nereprodukoval tř́́dní rozdíly, nebot' jachtaři se rekrutovali z odlišných socio-kulturních pozic. Rozdíly mezi nimi byly navíc radikálně zmenšeny politikou komunismu. Jachtařské regaty byly zároveň ostrůvkem neformálnosti, která existovala současně s komunistickou obsesí pravidly a formalizovanými procedurami (terénní poznámky, např́íklad zasedání VV ČSJ, Praha, 19. dubna 2007; lokální regata, Srby, 19. května 2007).

Citlivost k období okouzlení a jeho transformaci není jen výsadou střední a starší generace, ale zrovna tak se promítla do historek mladších jachtařů. To je dobře popsáno ve vyprávění jachtařky, které bylo v roce 1989 dvanáct let. Z pohledu ,,ditěte, který najednou jako nevědělo co dál " popisuje situaci politické transformace následovně:

Ten přelom jako byl takovej těžkej, si myslím, že to obdobi po tý revoluci, protože si myslím, že tady se docela do toho jachtingu stahovali lidi, kteři byli šikovní a chtěli něco dělat a nějak se realizovat, že si stavěli ty lodě. [...] Takže se o nás starali. [...] A měli jsme autobus a jezdili jsme jako, tak ve velkým to bylo, že se vyvařovalo [...] a starali se o nás pěkně.

\section{Hrozby odkouzlení: Výzvy (post-)transformace}

[Pokračování citace z předchozí části] A ted'ka po té revoluci to bylo najednou, že všichni začli podnikat a že byli rádi, že můžou něco dělat, tak tady nějaký starosti o nějaký cizi děti, když to tak řeknu, tak to docela vymizelo. Mně to mrzelo, docela. [...] Myslím si, že my a ty lidi kolem mě v tom ročníku, že jsme to jakoby odnesli.

Př́́mé vnímání změn, nahlížených mladou dobrovolnicí, obsahuje několik detailů (post-) transformačních procesů, a to zejména odkouzlující tendence, jež se v českém jachtingu objevují po sametové revoluci. Za prvé, sametová revoluce přinesla řadu změn v dimenzi politické. Ideologický nepř́tel v podobě komunismu se vytratil, stejně jako sociálně-svazující spiklenectví inherentní v ilegálních nebo únikových činnostech. Sdílené tajemství, jak bojovat s politickým nepřítelem, pozbylo na své sociální důležitosti.

$\mathrm{S}$ politickou svobodou byla spjata i svoboda $\mathrm{v}$ oblasti ekonomických a materiálních podmínek. Neziskový sektor se musel v období devadesátých let vyrovnat s dvojím břemenem. $\mathrm{V}$ důsledku pádu komunismu dříve početné zástupy dobrovolníků opustily sportovní sektor, aby se mohly chopit nových pracovních a kariérních príležitostí. Nové socio-kulturní a ekonomické podmínky navíc otevřely nové horizonty volného času, které jachtingu mnohdy konkurovaly. Tento fenomén byl navíc posílen globalizačními trendy.

Jeden $\mathrm{z}$ funkcionářu aktivních $\mathrm{v}$ jachtingu po desetiletí prohlásil: „Ve dne už nemá nikdo čas, všichni hrabou až do večera.“ Dané tvrzení odkrývá jeden ze symptomů rozsáhlejších trendů, jež po revoluci ohrožovaly jachting - nedostatek času. Ten, stejně jako zvýšená 
sociální mobilita, proměna aktivního trávení volného času vlivem rozvoje informačních technologií a demografické změny, přispěl k oslabení občanské angažovanosti. Daný sociální vývoj se odrážel i ve sportu, konkrétně v nedostatku trenérů a funkcionářů, a v důsledku toho i v poklesu sportovní participace. Takový trend je patrný i ze statistik ČSJ; zatímco v roce 1989 se alespoň jednoho závodu zúčastnilo 3777 jachtařů, v roce 2006 už to bylo pouze 1686 (ČSJ 2006).

Ekonomická podpora ze státem vlastněných továren byla přerušena, a jachtaři museli posílit svoji již tak značnou ekonomickou nezávislost. Otevření českého trhu a nově dostupné sportovní vybavení přispěly $\mathrm{k}$ vnitřní diferenciaci jachtingového hnutí. Pouta rovnostáŕství byla oslabena a někteří jachtaři dokonce zanechali svých sportovních aktivit, protože si nemohli provozování jachtingu z materiálních důvodů dovolit. Některé z vážených historických osobností jachtařského hnutí se dokonce vyjádřily ve smyslu, že ,jachting je dnes sportem pouze pro bohatéc. Silná okouzlující vazba založená na principu „udělej si sám“ vymizela, nebot' vybavení bylo najednou snadno dostupné za peníze, aniž by ho jachtaři museli podomně vyrábět:

Jachting se změnil obrovsky [...]. [Ti, kdo mají penize] utloukli všechny ty takový domácí závodníky tím, že si koupi třeba Fireballa za pưl milionu, nechá si ho dovézt z Anglie no a potom září. No tydlety lidi to naštve, nebo neni to pro ně príjemný. Ted' jde vo ten moment, že von se vo to stará, von se s tim babrá, a tenhleten to přiveze a hop! (muž, starši generace)

Některé jachtingové kluby dokonce zanikly kvůli vlastnickým sporům. V několika př́padech bylo vlastnictví jachetních oddílů (zpravidla pozemky) navráceno bývalým majitelům. V jiných, byt' spiše výjimečných prípadech, rozprodali vlastníci jachetních klubů společný majetek s cílem osobního obohacení.

Diferenciace jachtařŭ, ubývání dobrovolníků a pokles účasti na regatách ohrozily ze sociálního pohledu soudržnost jachtingového hnutí. Jednota komunity se stala záležitostí minulosti. Jachtařské hnutí bylo diverzifikováno a zasaženo trendy individualizace. Zejména nejstarší jachtaři si stýskají na proměněnou společenskou atmosféru a na absenci většího smyslu pro komunitu.

Dělali jsme všechno společně, zpívalo se, nakládali jsme lodě na auta společně. Dneska ty mladý to ani moc nezajímá, jsou to větší individualisti. Prostě jenom přijedou na závod, ale nezajímají se o jeho organizaci. Dř́v jsme i víc závodili, ted'ka by si každej hned sbalil lod' a vrátil se domů. Lidi už nezůstávaj přes noc. (žena, starší generace)

Oslabené vazby jsou do jisté míry i důsledkem proměněných vzorců komunikace. Snižená intenzita sociálních setkání a $\mathrm{v}$ důsledku toho i pokles konverzací tváŕí $\mathrm{v}$ tvář byly hlubokým zásahem do okouzlujícího prátelství mezi jachtaři. Spolu s tím se začínají objevovat kritické názory $\mathrm{k}$ vnějším podmínkám, jež negativně ovlivnily jachting jako sport. Komercionalizace jachtingu je tak mnohými jachtaři pokládána za mechanismus, který narušuje okouzlující vazby mezi jachtaři a mezi jachtaři a jejich sportem (terénní poznámky, např́klad oblastní regata, 13. květen 2007, Máchovo jezero; dětský jachtingový tábor, Orlická přehrada, 13. srpna 2007). 
Co se týká sportovní dimenze, jednota jachtařské komunity utržila další ránu poté, co došlo ke značné diversifikaci jachtařŭ podle kvality. Jak vysvětluje jeden trenér postoj některých soupeřù k jeho svěřenkyni:

Bud' se člověk smíř́ s tím, že bude dělat jakoby pro zábavu ten jachting, a pak může jezdit na čemkoli kdekoli, nebo se rozhodne závodit, a to prostě stoji nějaký penize. [...]. Spousta těch lidí, kteři se jakoby vyprofilovali do toho vrcholovýho jachtingu, tak je lidi přestali mit rádi a vlastně neradi s nima závodí, protože to cítí jako nefér, že jsou tak dobří... Ale je to nesmyslný, že jo? (muž, mladši generace)

Kromě vnitřních sporů a nedorozumění byla dalším symptomem odkouzlení skutečnost, že jachting z některých lokalit zcela zmizel, at' už kvưli nedostatku dobrovolníkủ nebo mizejícím loděnicím. Některé jachetní oddíly navíc bývalí jachtaři zrekonstruovali v rekreační areály, když využili atraktivní polohy loděnic, zanechali sportovních aktivit a využili pozemky $\mathrm{s}$ nevyjasněným otázkami vlastnictví klubů $\mathrm{k}$ výstavbě chatek. Jeden $\mathrm{z}$ jachtar̆u popisuje jednu z takových oblastí, která se stala rájem rybárư, následovně:

Dneska, když prijiedete na Nechranice, tak vlastně zjistite, že ten jachtař je ten poslední, kdo tam má co dělat, protože dneska, v podstatě, je tam ráj rybář̀i. [...] Na začátku je klub, který máte oplocený a kde se ani po šesté hodině nedostanete, protože tam žádná klubovna nefunguje. [...] Ty chatuše, které tam jsou na začátku, které kdysi pronajímali, a kde se dalo spát, tak každý u toho má přistavenou pětimetrovou verandu, zastřešenou a funguje mu to jako rekreačni domek. [...] Tam jak byly ty záchody, kdysi tam býval takový př́střešek, kde se sedělo, kde se hrálo na kytary do dvou hodin v noci a kde právě bylo to jachtařské živo... tam dneska tam jsou postavené obytné bydliky, které tam stoji. (muž, starši generace)

Porozumění postavení jachtingu po listopadu 1989 v pěti dimenzích naznačuje, že povaha jachtingu byla zásadně transformována a že důsledky takové proměny byly z pohledu předchozího okouzlení škodlivé. Jak naznačí další výklad, proměna sportovní kultury nebyla zdaleka jen negativní.

\section{Jachting opětovně okouzlující: Více YouTube a méně táboráků}

Navzdory novým trendům a podmínkám, jež přinesly hrozby odkouzlení, se jachtařum otevřely nové horizonty, které vazby mezi nimi posilovaly, a zároveň vnesly do vztahu jachtařu ke sportu nové okouzlující impulzy. Jachtaři se dokázali s některými hrozbami odkouzlení vypořádat a současně opětovně naplnili někdejší aspekty okouzlení novými významy tím, že se zhostili nových príležitostí. Současně s odkouzlením je tak třeba porozumět po-revolučnímu jachtingu jako opětovně okouzlujícímu.

Hlavního politického nepřítele $\mathrm{v}$ podobě komunistického režimu vystřídali noví nepřátelé a kolektivně sdílený boj s nimi. Přestože intenzita a dopad takových střetů nebyly zdaleka tak silné a intenzivní jako v minulosti, jachtaři našli nového nepřítele v ČSTV. Tento střešní sportovní svaz pro mnohé z nich představuje kontinuitu s minulým režimem, až už jde o minulost, byrokratickou strukturu a napojení na národní stát. Neúčinnost, způsob řízení sportu a mechanismy redistribuce finančních prostředků prriměly prezidenta jachtingového svazu, za podpory 
dalších jachtařŭ, $\mathrm{k}$ otevřenému boji proti střešní asociaci (terénní poznámky, vyhlášení ankety Jachtar̆ roku, Praha, 6. února 2007; sídlo ČSJ, Praha, 7. března 2007; <http:॥www.cere.cz>).

Kritika komercionalizace může být vnímána jako další ideologický aspekt, který vyživoval nesouhlas některých skupin, jež krystalizovaly v rámci hnutí. Problémy spjaté s již zmíněnou restitucí reprezentují jiný typ střetu. Někteří představitelé jachetních oddílů jsou tak nuceni trávit stovky hodin řešením právních otázek. „My máme výbor a ta výborová schůze dvě třetiny jedná ne o jachtingu, ale o všelijakejch právních, soudech a těhle potížích.“

Z ekonomické perspektivy bylo (post-)transformační období okouzlující pro jachting dvěma odlišnými způsoby. Někteří jachtaři, na jedné straně, posílili vazby ke svému sportu tím, že se pro ně jejich koníček stal prací. Jachting se pro ně stal predmětem podnikání, at' už ve sfére obchodu a výroby jachtingového vybavení a lodí, nebo v oblasti sociálně-budovatelské, nabízejíce teambuildingové a podobné aktivity. Atraktivita produktů globálního trhu a zvýšená možnost výběru pak př̌edstavují jiný aspekt ekonomického a specificky komoditního okouzlení.

Na straně druhé je možné pozorovat strukturální podobnost s ekonomickou skromností komunismu. Př́iběhy o skromnosti nadále představují důležitou součást žité zkušenosti jachtařŭ, at' už se týkají jejich vybavení nebo cestování. Otec jedné z nejlepších českých jachtařek $\mathrm{s}$ úspěchy na evropské úrovni popsal cestování na regaty v zahraničí následovně:

Trávím dva měsice v roce na parkovištích po Evropě. Přespáváme v autě, většinou, že jo. [...] Takový ti jako jsme my, tak spáváme u té maríny. A to jsou parkoviště, to jsou veřejný parkoviště uprostřed města. [...] Tam je vyhrazenej prostor špagátem a tam my spíme. Takže to korzo, který chodí, tak nám chodi dva metry od auta a tam chodijou ti korzaři v sobotu, v nedělu se nás dívaj jak na opice, jak my tam jako žijeme... (muž, středni generace)

Co se týká sociální dimenze, přátelské vztahy byly rekonfigurovány podobně. Jachtařské závody na jedné straně nadále doprovází hraní na kytary, táboráky, zpívání nebo společenské popíjení piva. Udržela se dokonce i tradice ski regat, nicméně jsou méně časté a jsou menší než v minulosti (terénní poznámky, např́íklad regata na národní úrovni, Nové Mlýny, 29. záŕí 2007; trénink v jachtingovém oddíle, Praha, 25. dubna 2007).

Toto okouzlení už nereprezentuje koherentní jednotu. Okouzlující vztahy jsou stále častěji dílem sociálních ostrůvků, které pevně spojují své „,̌leny“. Povaha takových ostrůvků, jež se ustavují jako produkty ekonomických nerovností a odlišných světonázorů, může být vystižena $\mathrm{v}$ termínech diverzifikovaných opětovných okouzlení. Diverzita jachtingového hnutí může být představena na rozdílu mezi konzervativními jachtaři, které spojuje nostalgie po minulosti, na straně jedné, a skupinami silně soutěživých jachtařů, již podporují komercionalizaci sportu, na straně druhé. Diverzifikace nicméně nevede ke konfliktům nebo $\mathrm{k}$ nedostatku tolerance. Spíše to znamená, že okouzlený vztah k jachtingu může být živen jak diverzitou, jež se objevuje v (post-)transformačním období, tak dědictvím a kontinuitou s minulostí. To je nejzjevnějš́ ve sfére řízení sportu. Sociální vztahy ustavené v průběhu neformálních setkávání v komunistickém období posloužily jako báze pro organizaci a řízení jachtingu v rámci ČSJ. Sociální sítě založené na důvěře a interpersonální př́mé zkušenosti dohromady přispěly k vytvoření jádra klíčových funkcionářu ČSJ, což umožňuje řízení svazu relativně neformálním způsobem. Tato transformace, nebo spíše kontinuita a rekonfigurace sociálních 
vztahů přispěla ke specifickému, téměř komunitními stylu organizace a řízení sportu, pro než je typická neformálnost. Členové jachtingové svazu si tykají a oslovují se přezdívkami, čímž je značně usnadněna komunikace (terénní poznámky, např́iklad výkonný výbor, Praha, 19. dubna 2007; dětský jachtingový tábor, Brno, 17. srpna 2007).

I když je jachting obecně vnímán jako individuální sport, mnozí jachtaři hovoří o jachtingu jako o sportu kolektivním, když poukazují na jeho společenskou povahu. Sociální pojivo je posíleno posilováním již ustavených známostí, což usnadňuje i skutečnost, že jachting byl zpravidla přenášen $z$ generaci na generaci. Podobným způsobem jsou i vzory opětovného okouzlení v symbolické dimenzi založeny na silném dědictví z minulosti. Sdílená prožitá zkušenost popsaná výše je svébytnou součástí kolektivní paměti jachtingového hnutí.

Nové formy komunikace navíc slouží jako nové platformy symbolického okouzlení. I když sestávají spíše z nepř́mých a virtuálních forem komunikace, zaručují jistou frekvenci setkání a nabízejí nové mechanismy symbolického poutání jachtařù $\mathrm{k}$ jejich sportu. Jachtařská komunita se stala virtuálnějši tím, že nahradila bývalé přímé kontakty nepř́mými vztahy zprostředkovanými skrze nové technologie. Jak jeden z jachtařu ze starší generace poznamenal k YouTube:

Zjistil jsem, že tam jsou tak nádherný jachtařský šoty. Moji kluci jsou zažraný do fotbalu, jo, a hrálo Česko s Belgii. A v obýváku hrála televize s fotbalem, já jsem si tam pouštél jachtařský klipy a kluci stáli u mě a koukali na počitač. Tam byly nádherný záběry, tam nějakej Chorvat tam má ze závodu čtyřistasedmdesátek, kdy podle mě to fouká hodně près patnáct metrů [...]. To jsou vopravdu záżitky, no.

Optikou symbolické dimenze nový, byt' stále vzácný důraz na sociální zodpovědnost sportovních klubů, environmentální témata nebo vzdělávání prèedstavují vynořující se témata $\mathrm{k}$ diskusi, které potenciálně posilují proces opětovného okouzlování. To je zjevné v následujícím tvrzení o popularitě stříbrné medailistky z Olympijských her v Aténách v roce 2004: „Je prŕijemný slyšet, že je tam desetiletá holčička, která má pokoj vyzdobenej fotkama Lenky Šmídový a že její idol je Lenka Šmídová“ (muž, střední generace). Tento komentář zdůrazňuje sportovní dimenzi okouzlení, která je čím dál častěji založena na mezinárodní reputaci. Nová dimenze opětovného okouzlení je navíc u vrcholových sportovcủ živena zvýšeným zájmem o závodní techniky, rozvojem technologií ve výrobě lodí, zájmem o trenérské metody či rostoucím použitím informačních technologií.

\section{Závěr}

Tato stat' se soustředila na vývoj v českém jachtingovém hnutí v uplynulých dvou desetiletích. Prostřednictvím etnografických př́běhů ukotvených v teoretickém rámci odkouzlení, okouzlení a opětovného okouzlení ukázala, že jachting zůstává v České republice pro jeho provozovatele nadále okouzlující, a to i navzdory hrozbám odkouzlení, kterým byl vystaven po roce 1989. Sociologická interpretace transformace žité zkušenosti post-komunistické sportovní kultury nabízí několik implikací nejen pro sociologii sportu, ale pro sociologii obecně.

$\mathrm{Z}$ analytického pohledu, $\mathrm{v}$ protikladu $\mathrm{k}$ převažujícím meta-naracím o komunistickém režimu v zemích střední a východní Evropy, jež chápaly sportovní kulturu jako podřízenou 
politickému řádu (Kostka 1978, Riordan 1999, Roubal 2003), podporuje tato analýza myšlenku, že sport může posílit rezistenci vůči hegemonní politické ideologii. Sféra sportu tak není vnímána coby výhradně ovládána vnějším politickým nebo ekonomickým světem, ale také jako prostor, který může potenciálně přispět k sociální změně.

Článek navíc naznačil, do jaké míry byl sport inherentní součástí transformačních procesů. Tyto procesy nebyly chápány výlučně $\mathrm{v}$ termínech lineární historie, s radikální změnou způsobenou sametovou revolucí v roce 1989. Zvláštní pozornost tak nebyla věnována pouze zlomům způsobeným politickou změnou, ale zároveň i dědictví předchozího komunistického režimu. Současně s rozdíly a odlišnostmi je tak při analýze transformačních procesů věnována pozornost podobnostem a kontinuitě s minulostí (Konopásek 1999).

Takové vnímání transformace je spjato se specifickou epistemologickou pozicí. Ve stati zdůrazňuji, že povaze současného sportu lze porozumět coby produktu dynamiky mezi procesy odkouzlení a (opětovného) okouzlení, přesněji, mezi procesy odkouzlování a (opětovného) okouzlování. Tyto procesy jsou ovlivněny širšími makro-sociálními kontexty, v nichž je soudobý sport uskutečňován, a sociální konstrukcí významu, který mu jeho provozovatelé přikládají. Jak naznačuje empirická evidence, provozovatelé sportu si často dokáží odkouzlující vnějšś podmínky přisvojit a dát jim význam přirozeného.

\section{Poděkování}

Tato stat' vznikla za finanční podpory Evropské komise v rámci šestého Rámcového programu a grantu Marie Curie Excellence Grant MEXT-25008 „Sport and Social Capital in the European Union“, který byl udělen Margaret Groeneveld a Univerzitě Bocconi. Rád bych za cenné poznámky a kritické připomínky poděkoval třem anonymním recenzentům časopisu Sociology a mým kolegům ze sportovního projektu, kterými jsou: Cristina Fusetti, Thomas Persson, Giovanni Fattore a Margaret Groeneveld. V neposlední řadě bych moc rád poděkoval také všem jachtařům za vstřícnost, otevřenost a pochopení, s nimiž přijali moje, pro mnohé z nich možná trochu nezvyklé výzkumné úsilí.

\section{Literatura}

ALEXANDER, Jeffrey C. Cultural Pragmatics: Social Performance between Ritual and Strategy. Sociological Theory, 2004, č. 22, s. 527-73. ISSN 1467-9558.

AVERSA, Alfred Jr. Notes on Entry Routes into a Sport/Recreational Role: The Case of Sailing. Journal of Sport and Social Issues, 1986, roč. 10, č. 2, s. 49-59. ISSN 1552-7638.

BASS, Jay. The Enjoyment of Fear: Sailing and Lived Emotion. Free Inquiry in Creative Sociology, 1990 , roč. 18, č. 2, s. 145-50. ISSN 0736-9182.

BECK, Ulrich. Riziková společnost. Praha: Slon, 2004 [1992]. 431 s. ISBN 8086429326

BENNETT, Jane. The Enchantment of Modern Life: Attachments, Crossings, and Ethics. Princeton, NJ: Princeton University Press, 2001. 213 s. ISBN 978-0691088136.

BOURDIEU, Pierre. Sport and Social Class. Social Science Information, 1978, roč. 17, č. 6, s. 819-840. ISSN 1461-7412.

BOURDIEU, Pierre. Distinction: A Social Critique of the Judgement of Taste. Cambridge, MA: Harvard University Press, 1984. 613 s. ISBN 9780415045469. 
BRICKNELL, Louise. The Trouble with Feelings: Gender, Sexualities, and Power in a Gender Regime of Competitive Sailing. Journal of Sport and Social Issues, 1999, roč. 23, č. 4, s. 421- 38. ISSN 1552-7638.

CAMPBELL, Colin. L'etica romantica e lo spirito del consumismo. Roma: Edizioni Lavoro, 1992. $352 \mathrm{~s}$. ISBN 9788879105064.

CANTELON, Hart; INGHAM, Alan G. Max Weber and the Sociology of Sport. In MAGUIRE, J.; YOUNG, K. (Eds.) Theory, Sport and Society. London: JAI Press, 2002, s. 63-81. ISBN 9780762307425.

CASEY, Catherine. Bureaucracy Re-enchanted? Spirit, Experts and Authority in Organizations. Organization, 2004, roč. 11, č. 1, s. 59-79. ISSN 1461-7323.

CASSEGARD, Carl. Murakami Haruki and the Naturalization of Modernity. International Journal of Japanese Sociology, 2001, roč. 10, č. 1, s. 80-92. 1475-6781.

COLES, Robert W. Football as a Surrogate Religion. In HILL, M. (Ed.) A Sociological Yearbook of Religion in Britain. London: SCM Press, 1975, s. 20-39. ISBN 9780334016281.

CRAWLEY, Sara L. Gender, Class and the Construction of Masculinity in Professional Sailing. International Review for the Sociology of Sport, 1998, roč. 33, č. 1, s. 33-42. ISN 1461-7218.

ČSJ. 100 let jachtingu. Praha: ČSJ, 1993.

ČSJ. Český jachting 1993-2003. Připravili Rudolf Holý a Miroslav Kryl. Praha: ČSJ, 2003.

ČSJ. Ročenka ČSJ 2006. Praha, 2006.

DUNNING, Eric. The Dynamics of Modern Sport: Notes on Achievement - Striving and the Social Significance of Sport. In ELIAS, N.; DUNNING, E. (Eds.) The Quest for Excitement. Oxford: Blackwell, 1986, s. 205-23. ISBN 9780631146544.

DUNNING, Eric. Sociology of Sport in the Balance: Critical Reflections on Some Recent and More Enduring Trends. Sport in Society, 2004, roč. 7, č. 1, s. 1-24. ISSN 1743-0445

ELIAS, Norbert; DUNNING, Eric. The Quest for Excitement in Leisure. In ELIAS, N.; DUNNING, E. (Eds.) The Quest for Excitement. Oxford: Blackwell, 1986, s. 63-90. ISBN 9780631146544.

FALT, Pierre. Les usages sociaux de la croisière. In POCIELLO, C. (Ed.) Sports et société. Paris: Vigot, 1981, s. 261-84. 377 s. ISBN 9782711408221.

FRANKENBERG, Ronald. Village on the Border: A Social Study of Religion, Politics and Football in a North Wales Community. London: Cohen \& West, 1957. 223 s. ISBN 9780881334852.

GANE, Nicholas. Max Weber and Postmodern Theory: Rationalization versus Reenchantment. London: Palgrave, 2002. 208 s. ISBN 9781403941169.

GELL, Alfred. Technology and Magic. Anthropology Today, 1988, roč. 4, č. 2, s. 6-9. ISSN 0268-540X.

GELLNER, Ernst. Culture, Identity and Politics. Cambridge: Cambridge University Press, 1987. 200 s. ISBN 9780521334389

GIULIANOTTI, Richard. Jean Baudrillard and the Sociology of Sport. In Giulianotti, R. (Ed.) Sport and Modern Social Theorists. London: Palgrave Macmillan, 2004, s. 225-40. 264 s. ISBN 9780333800782.

GUTTMANN, Allen. From Ritual to Record: The Nature of Modern Sports. New York: Columbia University Press, 1978. 198 s. ISBN 9780231133418.

HANN, Chris. Rozmanité časové rámce antropologie a její budoucnost ve střední a východní Evropě. Sociologický časopis, 2007, roč. 43, č. 1, s. 15-30. ISSN 0038-0288.

INHGMAN, Alan G. The Sportification Process: A Biographical Analysis Framed by the Work of Marx, Weber, Durkheim and Freud. In Giulianotti, R. (Ed.) Sport and Modern Social Theorists. London: Palgrave Macmillan, 2004, s. 11-32. ISBN 9780333800782

JENKINS, Richard. Disenchantment, Enchantment and Re-enchantment: Max Weber at the Millennium. Max Weber Studies, 2000, č. 1, s. 11-32. ISBN 1470-8078. 
KONOPÁSEK, Zdeněk. Reflexivní autobiografie interpretací post/komunistického Východu k porozumění post/modernímu Západu. In Konopásek, Z. (ed.) Otevřená minulost. Autobiografická sociologie státního socialismu. Praha: Karolinum, 1999, s. 353-69. ISBN 9788071847557.

KORCZYNSKI, Marek; OTT, Ursula. The Menu in Society: Mediating Structures of Power and Enchanting Myths of Individual Sovereignty. Sociology, 2006, roč. 40, č. 5, s. 911-928. ISSN 1469-8684.

KOSTKA, Vladimír. Czechoslovakia. In Riordan, James. (Ed.) Sport under Communism: A Comparative Study. London: C. Hurst, 1978, s. 55-66. ISBN 9780773505056.

LANGER, Beryl. Commodified Enchantment: Children and Consumer Capitalism. Thesis Eleven, 2002, roč. 69 , č. 1 , s. 67-81. ISSN 1461-7455

MACBETH, Jim. Ocean Cruising: A Sailing Subculture. Sociological Review, 1992, roč. 40, č. 2, s. 319-43. ISSN 1467-954X.

NUMERATO, Dino. Mediální pole: mezi zakouzlením a odkouzlením. Revue pro média, 2005a, č. 12/13, s. 72-80. ISSN 1211-9938.

NUMERATO, Dino. Odkouzlená média. Disertační práce, Masarykova universita v Brně, 2005b.

PORRO, Nicola. Lineamenti di sociologia dello sport. Roma: Carocci, 2002. 212 s. ISBN 9788843018659.

RIORDAN, James. The Impact of Communism on Sport. In Riordan, J.; Krüger, A. (Eds.) The International Politics of Sport in the 20th Century. London: EF \& N Spon, 1999, s. 48-66. ISBN 9780419211600.

RITZER, George. Enchanting a Disenchanted World. Revolutionizing the Means of Consumption. London: SAGE, 1999. 280 s. ISBN 9780761985112.

RITZER, George; STILLMAN Todd. The Postmodern Ballpark as a Leisure Setting: Enchantment and Simulated De-McDonaldization. Leisure Sciences, 2001, roč. 23, č. 2, s. 99-113. ISSN 1521-0588.

ROUBAL, Petr. Politics of Gymnastics: Mass Gymnastic Displays under Communism in Central and Eastern Europe. Body \& Society, 2003, roč. 9, č. 2, s. 1-25. ISSN 1460-3632.

SCHEERDER, Jeroen; VANREUSEL Bart; TAKS, Marijke; RENSON Roland. Social Sports Stratification in Flanders 1969-1999: Intergenerational Reproduction of Social Inequalities? International Review for the Sociology of Sport, 2002, roč. 37, č. 2, s. 219-45. ISSN 1461-7218.

SCHNEIDER, Mark A. Culture and Enchantment. Chicago, IL: University of Chicago Press, 1993. 240 s. ISBN 9780226739274.

SILVERSTONE, Roger. Why Study The Media? London: SAGE, 1999. 176 s. ISBN 9780761964537.

SIMMEL, Georg. The Stranger. In Wolff, K. H. (Ed.) The Sociology of Georg Simmel. New York: Free Press, 1950, s. 402-408. ISBN 9780029289204.

SOJAK, Radoslaw. The Enchantment of the Social. In ELIAESON, S. (Ed.) Building Democracy and Civil Society East of the Elbe. London: Routledge, 2006, s. 238-247. ISBN 9780415368094.

WEBER, Max. Science as a Vocation. In GERTH, H. H.; MILLS, C. W. (Eds.) Essays in Sociology. New York: Oxford University Press, 1971, s. 129-56. ISBN 9780195004625.

WEBER, Max. Metodologie, sociologie a politika. Praha: Oikoymenh, 1998.354 s. ISBN 9788086005485.

\section{Autor}

Dino Numerato je výzkumník na Univerzitě Bocconi v Miláně (Department of Policy Analysis and Managament a CERGAS), kde se zabývá epidemiologií a sociologií zdravotní péče. Získal doktorát v oboru sociologie na Fakultě sociálních studií Masarykovy univerzity v Brně, kde externě přednáší sociologii sportu.

Kontakt: dino.numerato@unibocconi.it 